\title{
Katarzyna Świetlik
}

https://orcid.org/0000-0002-3742-6895

Uniwersytet Jana Kochanowskiego w Kielcach

\section{Paweł Woś}

https://orcid.org/0000-0003-3346-1674

Uniwersytet Jana Kochanowskiego w Kielcach

\section{„Gdzie kilka kobiet weźmie się za sprawę...”, czyli emancypacja na przykładzie Marii Dulębianki}

Słowa kluczowe: Maria Dulębianka, feminizm, Związek Równouprawnienia Kobiet, Liga Kobiet, „Głos Kobiet”, Lwów

\section{Streszczenie}

Głównym celem artykułu jest przypomnienie postaci zasłużonej działaczki, artystki, feministki i patriotki, Marii Dulębianki (1862-1919), od śmierci której minęło sto jeden lat. Jednak to nie rocznica, a działania, jakich podejmowała się Dulębianka, posłużyły za główną motywację do przygotowania niniejszego artykułu. Pomimo nieprzychylnych postaw prezentowanych przez mężczyzn względem kobiet, które objawiały się m.in. w braku dostępu do edukacji na akademiach sztuk pięknych, co dotknęło artystkę personalnie, M. Dulębianka „zrzuciła patriarchalne okowy” i postanowiła walczyć nie tylko o kobiety, ale i całą narodową sprawę. Początkowo batalia ta miała charakter bardziej spontaniczny, bez konkretnego, opracowanego planu, bez organizacji, jednak to właśnie te żywiołowe działania, jak choćby zamieszczane w prasie artykuły autorstwa Dulębianki, czy uczestnictwo, a także organizacja licznych wieców, uczyniły pewnego rodzaju wyłom. Aktywność bohaterki na polu społeczno-politycznym, ale również kulturalno-oświatowym, doskonale wpisuje się w istniejący model kobiecych wyobrażeń i perspektyw na drodze ku równouprawnieniu. Próba spojrzenia na postać zasłużonej Polki przez pryzmat jej życia, zarówno publicznego, jak i prywatnego, pozwala na ukazanie pełnego wachlarza indywidualnych postaw, które cechowały Dulębiankę w celach, jakie sobie postawiła. Nawoływania nie tylko skierowane do kobiet, ale także, a może przede wszystkim, do mężczyzn o prawach płci pięknej do wykształcenia, jak i samostanowienia niejednokrotnie splatały 
się z hasłami równouprawnienia wszystkich warstw społecznych, w czym widziała jedyną drogę do odzyskania niepodległości.

\section{Wprowadzenie}

Na przełomie XIX i XX w. kobiety coraz liczniej angażowały się w działalność publiczną, wychodząc poza tradycyjne formy aktywności. Przestawały być „zakładniczkami” gospodarstwa domowego. Zaczęły:

konfrontować się z warunkami niesprzyjającymi rozwojowi solidaryzmu kobiecego jak patriarchalny model społeczeństwa. Pomimo iż w mentalności społecznej istniała gotowość do powszechnego aprobowania „naturalnych” kobiecych ról społecznych, to aktywność kobiet na polu zawodowym, politycznym czy czynności związane ze zdobyciem wykształcenia, na ogół nie były tolerowane ${ }^{1}$.

Wiktoria Hozerowa, przed stu laty dała podobny obraz sytuacji kobiet. „Żyją one w lęku, przygniecione «głazem stosunków we wszystkich dziedzinach życia»". Zniewolone rolą gospodyń domowych, odseparowane od życia towarzyskiego i brakiem perspektyw na przyszłość, skrępowane modelem społeczeństwa utrwalonego w tradycji chłopskiej, nie miały możliwości uwolnić się z okowów panujących stosunków społecznych. Kobiety, niegdyś gwarantki życia towarzyskiego salonów polskich, dzisiaj zepchnięte z piedestału orędowniczek myśli postępowych „oddały klucze wewnętrznych kościołów rozlicznym panom, którzy kultywują w nich zgniliznę, nie dopuszczając świeżego prądu powietrza"².

Bezwzględnym tyranem, który zniewolił kobiety, była opinia publiczna. Uzewnętrznianie indywidualnych cech ,siostrzyc spod strzechy”, jak i podejmowane próby wyzwolenia się ze świata, który miał być dla nich „więzieniem, a życie katem”, były boleśnie karane. „Niesolidarny warchoł!” - o to co mogły usłyszeć kobiety próbujące uwolnić się spod tyranii form, kast i stronnictw. Kiedy usiłowały oprzeć wiedzę o nowe prądy umysłowe zyskiwały stampilę - „,bezbożnik”3. W podobnym duchu w 1883 r. Ludwik

E. Maj, Wzorce aktywności kobiet w Narodowej Demokracji (1893-1939), [w:] T. Kulak, M. Dajnowicz (red.), Drogi kobiet do polityki (Na przestrzeni XVIII-XXI wieku), Wydawnictwo Chronicon, Wrocław 2016, s. 148-149.

2 W. Hozerowa, Wyrabiajmy w sobie samodzielna dusze, dodatek do „Kuriera Lwowskiego”, „Głos Kobiet” 1911, nr 128, s. 6.

3 Ibidem. 
Masłowski, redaktor „Kuriera Lwowskiego”, wyrażał swoje przekonania. Obarczając winą kobiety, jednocześnie widział w nich olbrzymi potencjał:

Gdzie nie ma salonów, jest to dowód, że tam kobiety nie dorosły do tego kwiatu społecznego; one są winne, bo tylko one mogą salony utrzymywać. Bez salonów zaś nie ma źródeł, nie ma ognisk, z którychby wychodziły zawsze pomysły, zachęty, przykłady, inicjatywa, ochota do życia i pracy, wreszcie gdzieby się wytwarzała opinia zdrowa i potężna ${ }^{4}$.

Dążenia, aby takie hasła jak „,naród i solidarność”, stały się iskrą, która pobudza człowieka do twórczego życia, wyzwala z egoizmu, a nakazuje podążać do wielkiego dzieła odrodzenia narodowego, w praktyce okazały się bronią obusieczną. Ślepe oddanie się podobnym formułom, bez zbadania ich treści, skutkowało unieruchomieniem życia społecznego, podporządkowaniem się egoistycznym interesom pewnych grup, o czym mogło przekonać się społeczeństwo galicyjskie. Wydawać by się mogło, że stosunki panujące w Galicji, uformowane przez rząd zaborczy, stanowiły ciemną kartę w historii narodu. Wiktoria Hozerowa odnotowywała:

Tak było po wszystkie czasy to baśń odwieczna, snująca się przez historię. Lekkomyślność w szafowaniu doniosłymi hasłami, wielokrotnie w historii narodu sprowadzała klęski na ojczyznę, której teraz społeczeństwo polskie zostało pozbawione. Przykład Żółkiewskiego, który obwołany przez olbrzymią większość sejmową zdrajcą narodu, większość sejmową, czyli tych, którzy ratowali się haniebną ucieczką spod Cecory, podczas gdy owy zdrajca „położył swą najcenniejszą głowę za honor ojczyzny”.

Opinia społeczna najtroskliwiej opiekowała się kobietą, jak również kobieta się z nią najbardziej liczyła. Pierwszą rzeczą na drodze ku wyzwoleniu kobiet powinno być wyrobienie samodzielności. Otóż samodzielność i twórczość stawały się pierwszym etapem, a zarazem stałym punktem rozwoju. Samodzielny człowiek kieruje się własną opinią, myślą i uczuciem, a na podstawie wewnętrznych przeżyć zaczyna tworzyć nowe wartości. Tak więc, jeśli ruch kobiecy ma okazać się czynnikiem zmieniającym zastałe stosunki społeczne, musi być twórczy, lecz przed tym musi się usamodziel-

Elin [Ludwik Masłowski], Nasze życie towarzyskie, „Kurier Lwowski” 1884, nr 64, S. 1.

W. Hozerowa, Wyrabiajmy w sobie..., s. 6; E. Jankowski (red.), Słownik pseudonimów pisarzy polskich XV w. - 1970 r., Wydawnictwo Zakładu Narodowego im. Ossolińskich, Wrocław 1994, s. 486. 
nić, a zatem uwolnić spod władzy „,przykazań i straszaków opinii”. W szakże opinia toleruje wyłącznie to co znane, ogólnie przyjęte, a więc często „przeżyte, zbutwiałe”. Zatem sposób postępowania zawarty w pamiętnym: „Przy tobie opinio wiernie stoimy i stać chcemy", należy bezpowrotnie odrzucić.

Podział społeczny uzależniony od kategorii płci odpowiadał tradycyjnemu modelowi rodziny patriarchalnej. Podział ów dominował na ziemiach polskich prawie przez cały XIX w., dopiero w ostatnim dziesięcioleciu zaczęły pojawiać się pierwsze szczeliny ${ }^{6}$. Pod wpływem przemian modernizacyjnych pod koniec XIX w. w postaci szeroko zakrojonej industrializacji oraz reform agrarnych dokonał się przełom $\mathrm{w}$ dziedzinie emancypacji ${ }^{7}$.

Działalność Dulębianki przypadła na okres przełomu XIX i XX w., tzn. w momencie dynamicznie zmieniającej się sytuacji politycznej i społecznej w Galicji od lat 90. XIX w., w sytuacji narastających dążeń niepodległościowych wyrażanych m.in. w postaci obchodów wielkich rocznic narodowych czy kulcie bohaterów powstania styczniowego, w okresie wzmożonej aktywności ruchów kobiecych. Próba spojrzenia na postać Dulębianki przez pryzmat jej życia publicznego i prywatnego, pozwala na przybliżenie pełnego wachlarza indywidualnych postaw, które cechowały Marię w dążeniach, jakie przed sobą postawiła. Pouczenia kobiet o ich prawach do wykształcenia, jak i o samostanowieniu o sobie, niejednokrotnie splatały się $\mathrm{z}$ hasłami równouprawnienia wszystkich warstw społecznych, ponieważ dostrzegano w tym działaniu jedyną drogę do niepodległości.

W dalszej części artykułu ukażemy na przykładzie Marii Dulębianki drogę jaką musiały pokonywać kobiety, gdyż artystka i działaczka nie tylko odrzuciła wyroki opinii publicznej, o czym świadczy chociażby jej trudny do jednoznacznego zdefiniowania z powodu braku dostatecznego materiału źródłowego „związek” z Marią Konopnicką , ale również fakt, iż Dulębianka

A. Żarnowska, Prywatna sfera życia rodzinnego i zewnętrzny świat życia publicznego - bariery i przenikanie (przełom XIX i XX wieku), [w:] A. Żarnowska, A. Szwarc (red.), Kobieta i świat polityki. Polska na tle porównawczym $w$ XIX i w początkach XX wieku, Wydawnictwo DiG, Warszawa 1994, s. 7.

$7 \quad$ T. Kizwalter, Procesy modernizacji a emancypacja kobiet na ziemiach polskich $w$ XIX wieku, [w:] A. Żarnowska, A. Szwarc (red.), Kobieta i społeczeństwo na ziemiach polskich w XIX w., Wydawnictwo DiG, Warszawa 1990), s. 6.

$8 \quad$ Więcej o ich relacji zob.: M. Szypowska, Konopnicka jakiej nie znamy, Państwowy Instytut Wydawniczy, Warszawa 1969; K. Tomasik, Homobiografie. Pisarki i pisarze polscy XIX i XX wieku, Wydawnictwo Krytyki Politycznej, Warszawa 2008. 
stała się samodzielną i twórczą przedstawicielką galicyjskiego ruchu kobiecego.

Podstawą naszej refleksji stała się postawa i zaangażowanie zwłaszcza w kwestię kobiecą Dulębianki, utrwalone w publicystyce społecznej w postaci broszur, pozycji o charakterze biograficznym, jakie powstały po śmierci tej wielkiej Polki jeszcze w międzywojniu, jak w „Kurierze Lwowskim”, czy następnie w „Głosie Kobiet”, dodatku do „Kuriera”, redagowanym przez M. Dulębiankę, który nie został dotychczas opracowany, czy też w okresie późniejszym9 . Jednak gros materiałów stanowi dokumentacja źródłowa, znajdująca się przede wszystkim w lwowskich zbiorach, tj. Lwowskiej Naukowej Bibliotece im. Wasyla Stefanyka w zespole $9^{10}$, Centralnym Państwowym Historycznym Archiwum Ukrainy w zespole $841^{11}$, czy Zakładzie Narodowym im. Ossolińskich we Wrocławiu ${ }^{12}$. Postać M. Dulębianki współcześnie nie doczekała się jeszcze opracowania monograficznego. W cytatach zamieszczonych $\mathrm{w}$ artykule zachowano oryginalną pisownię i interpunkcję.

$9 \quad$ M. Jaworska, Marja Dulębianka, Lwowska Liga Kobiet, Lwów 1929; E. Byk, Marya Dulębianka jako malarka. Z powodu pośmiertnej wystawy Jej utworów, „Wiek Nowy” 1919, nr 5405; H. Witkowska, Wspomnienia, „Na Posterunku. Tygodnik kobiecy poświęcony sprawom społecznym, ekonomicznym, pedagogicznym i etycznym pod kierunkiem literackim Heleny Witkowskiej”; Orlętom. Straż mogił polskich bohaterów. Przewodnik po cmentarzu obrońców Lwowa, Wydawnictwo Towarzystwo Straży Mogił Polskich Bohaterów, Lwów 1934; L. Michalska-Bracha, M. Marczewska, Lwowianki wobec równouprawnienia kobiet - trzy historie. Studium historyczno-językoznawcze, „Czasopismo Naukowe Instytutu Studiów Kobiecych” 2019, nr 1(6), s. 25-53; B. Walęciuk-Dejneka, Galicyjskie portrety kobiet - Maria Dulębianka, [w:] J. Kamińska-Kwak, D. Opaliński (red.), Kobieta w Galicji. Nowoczesność i tradycja, Wydawnictwo Uniwersytetu Rzeszowskiego, Rzeszów 2016, s. 271-281; J. Sosnowska, Maria Dulębianka przeciw samotności, [w:] A. Żarnowska, A. Szwarc (red.), Kobieta i rewolucja obyczajowa. Społeczno-kulturowe aspekty seksualności. Wiek XIX i XX, t. 9, Wydawnictwo DiG, Warszawa 2009, s. 457-469.

10 Lwowska Naukowa Biblioteka im. Wasyla Stefanyka we Lwowie, [dalej: BNSL], zesp. 9: Rękopisy Biblioteki Zakładu Narodowego im. Ossolińskich, sygn. 2675: Papiery Marii Dulębianki.

11 Dokładniej w zesp. 841, inw. 1, sygn. 122 oraz sygn. 159, w których znajduje się życiorys M. Dulębianki, a także materiały odnośnie Komitetu Równouprawnienia Kobiet we Lwowie.

12 Zakład Narodowy im. Ossolińskich we Wrocławiu [dalej: ZNiO], rkps 7191/II, k. 171; rkps 15512/II, k. 31, 32. 


\section{Życiorys}

(...) Życie spieszyło się, mknąc dzień za dniem, porywając za sobą wszystko co żywe, co dzielne, biorąc dla siebie wszystkie siły i pragnienia.

Do walki, do zwycięstwa!

Szybko zapomina się o ludziach! O tych, Którzy ongiś byli najpierwsi i o tych, Którzy byli najbliżsi... ${ }^{13}$

Maria Dulębianka, córka Henryka i Marii z Wyczółkowskich, przyszła na świat w Krakowie w 1862 r. Pochodziła z rodziny ziemiańskiej ${ }^{14}$. Jej starszy brat Władysław był znanym i cenionym adwokatem we Lwowie oraz wiceprezesem Koła Polskiego w parlamencie austriackim.

Uczęszczała na pensję pani Justyny Maliszewskiej, następnie ukończyła szkołę średnią w Krakowie, tutaj też rozpoczęła studia pod kierunkiem Jana Matejki oraz w międzyczasie w Warszawie u prof. Wojciecha Gerso$\mathrm{na}^{15}$, a kontynuowała je w Wiedniu i Paryżu w towarzystwie swej przyjaciółki Anny Bilińskiej ${ }^{16}$. Jej talent malarski został w dość krótkim czasie doceniony, gdyż wystawiała $\mathrm{z}$ powodzeniem swe prace $\mathrm{w}$ wieku już dwudziestu lat ${ }^{17}$, a potwierdzeniem powyższych słów był zakup obrazu artystki, Studium dziewczyny, przez Muzeum Narodowe, czy przyznanie jej parę lat od tego wydarzenia odznaczenia Mention honorable ${ }^{18}$ podczas międzynarodowej wystawy w Paryżu za Sieroca dolę i Na pokucie ${ }^{19}$ w 1900 r. O jej twórczości wypowiadali się pozytywnie i z uznaniem m.in. Stanisław Wit-

13 A. Strug, Z powrotem, Wydawnictwo: Księgarnia Bibljoteki Dzieł Wyborowych, Warszawa 1925, s. 116, 117.

Centralne Państwowe Historyczne Archiwum Ukrainy we Lwowie [dalej: CPHAUL], zesp. 841, inw. 1, sygn. 122, k. 94: Życiorys Marii Dulębianki.

M. Jaworska, Marja Dulębianka..., s. 1.

M. Dulębianka w Paryżu pobierała nauki u Tony’ego Roberta Fleury oraz Williama Adolfa Bourguereau, a także Carolusa Durana i Jana Jakoba Hennera, natomiast w Wiedniu szkoliła swój warsztat u Leopolda Horowitza: BNSL, zesp. 9, sygn. 2675, k. 299: Marya Dulębianka. Rzeczniczka etyki i równości obywatelskiej; E. Byk, Marya Dulębianka, s. nlb.

W latach 80. XIX w. przebywając w Paryżu, wysłała na wystawę Zachęty Sztuk Pięknych w Warszawie swój pierwszy, poważniejszy obraz o tematyce historycznej pt. Łokietek: BNSL, zesp. 9, sygn. 2675, k. 299: Marya Dulębianka. Rzeczniczka etyki i równości obywatelskiej.

E. Byk, Marya Dulębianka..., s. nlb. 
kiewicz, czy Stefan Żeromski. Dzieła M. Dulębianki to przede wszystkim portrety i studia, wykonane techniką olejną ${ }^{20}$.

Artystyczna działalność M. Dulębianki w pewnym momencie uległa spowolnieniu, nie można rzec, iż kompletnemu zatrzymaniu, gdyż w przyszłości nadal będzie pochylać się nad płótnami, jednak oddawała się swojej pasji nie w takim natężeniu, jak miało to miejsce dotychczas. Powodem zmiany, choć nie można tego stwierdzić z całkowitą pewnością, było spotkanie z M. Konopnicką, gdyż niemal cały swój czas podporządkowała przyjaciółce i kuracjom, na które ta musiała się udawać w celu podreperowania zdrowia ${ }^{21}$ oraz poświęcenie się walce o równouprawnienie kobiet.

M. Dulębianka po raz pierwszy spotkała poetkę w Warszawie, podczas pracy $\mathrm{w}$ organizacjach o charakterze narodowo-wyzwoleńczym ${ }^{22}$. Znajomość ta wówczas zawarta, przetrwała przeszło 25 lat, aż do śmierci M. Konopnickiej. Połączyły je wspólne zainteresowania i pogląd na sprawy bieżące. Czas spędzony na podróżach zdrowotnych M. Konopnickiej, nie był dla M. Dulębianki bezowocny, bowiem żywo interesowała się ruchami kobiecymi zorganizowanymi w ościennych państwach, wygłaszała przy tym odczyty, w których przedstawiała sytuację Polek i Polski. Zagraniczne wojaże, a także baczna obserwacja polityki krajowej oraz sprawy kobiecej wykształciła w niej przekonanie, iż uzyskanie przez kobiety praw wyborczych jest nie tylko konieczne, by wyzwolić je z okowów uciemiężenia, ale także by przynieść krajowi upragnioną niepodległość.

Przebywając wraz z M. Konopnicką w Żarnowcu ${ }^{23}$, M. Dulębianka udzielała bezpłatnych lekcji języka niemieckiego dzieciom kończącym szkołę elementarną, ponieważ był on wymagany przy egzaminach wstępnych do gimnazjum. Znajdowała także czas na malowanie, czego dowo-

$20 \quad$ Pełny obraz nie tylko talentu, ale także twórczości M. Dulębianki obrazowała pośmiertna, zbiorowa wystawa prac artystki i działaczki, zorganizowana w sali Towarzystwa Sztuk Pięknych w gmachu Muzeum Przemysłowego na ul. Dzieduszyckich. Wystawa ta obejmowała blisko kilkadziesiąt płócien: M. Jaworska, Marja Dulębianka..., s. 2; E. Byk, Marya Dulębianka..., s. nlb.

$21 \quad$ BNSL, zesp. 9, sygn. 2675, k. 299: Marya Dulębianka. Rzeczniczka etyki i równości obywatelskiej.

$22 \mathrm{ZNiO}$, rkps 15512/II, k. 31.

23 Żarnowiec został podarowany M. Konopnickiej głównie dzięki usilnym zabiegom $\mathrm{S}$. Wekslerowej, która „w tym celu nawiązywała kontakty z różnymi osobami i środowiskami (...), aż w dniu 8 IX 1903 wprowadziła Konopnicką do jej własnego domu”. Zob. S. Fita, Nieznane listy Marii Konopnickiej i Marii Dulębianki do Stefanii Wekslerowej: 1908-1910, „Pamiętnik Literacki” 2000, t. 91, z. 2, s. 181. 
dem jest m.in. obraz pt. List do matki. Nie miała znaczniejszych problemów ze sprzedażą dzieł, zarówno za granicą, jak i w kraju. Jednak prócz malarstwa, wolne chwile spędzała także na grze na skrzypcach, czy pianinie, czytywała namiętnie prasę polską oraz zagraniczną. Po śmierci poetki opuściła Żarnowiec i udała się do Lwowa, gdzie osiadła na stałe. Tam też w pełni poświęciła się pracy polityczno-społecznej.

\section{Aktywność}

M. Dulębianka była postacią nietuzinkową. Ów ekscentryzm objawiał się m.in. w sposobie ubierania, czy zachowaniu. Choć odznaczała się wysokim wzrostem, a także regularnymi rysami twarzy, nie eksponowała swojej atrakcyjności, wręcz przeciwnie, wybierała nie tylko męski krój stroju, jak krawat - kokarda, czy koszula z wystającymi mankietami, spiętymi złotymi spinkami, ale także typową męską fryzurę, tj. krótko obcięte włosy ${ }^{24}$. Prócz wyglądu, swe zapatrywania, m.in. na kwestię kobiecą, wyrażała poprzez stałą aktywność w organizacjach ruchu kobiet, które walczyły o równouprawnienie. Wobec tego brała udział w zjazdach Kobiet Polskich we Lwowie, przemawiała na międzynarodowym Kongresie Kobiet w Budapeszcie w 1913 r., uczestniczyła w zorganizowanym przez Towarzystwo Pomocy Naukowej dla Polek im. J.I. Kraszewskiego serii odczytów obejmujących całokształt kwestii kobiecejej, brała udział w Zjeździe Kobiet w Wiedniu w 1912 r. $^{26}$, z okazji okrągłej rocznicy Uniwersytetu Jagiellońskiego, zorganizowała III Zjazd Kobiet Polskich w Krakowie, który zgromadził liczne grono ok. dwóch tysięcy osób ze wszystkich zaborów. Jej walka o równość kobiet odbywała się przy użyciu przekonywujących argumentów:

Jest też zjawiskiem nie bez dziejowego znaczenia, że właśnie w tej chwili na politycznej arenie świata zjawiają się pierwsze forpoczty kobiece. Forpoczty hufców, które pójść muszą w bój za wszystkie ludzkie ideały, za wszystko co znieważono, za wszystko co cierpi, a żyć nie może. Te nasze hufce obroną i pomocą być muszą. Muszą być, jako rezerwa zachowane do ostatecznego zwycięstwa w decydującym momencie, by przyjść w sukurs walczącym,

ZNiO, rkps 15512/II, k. 31.

25 Maria Dulębianka podczas zorganizowanego w grudniu i styczniu 1902/1903 r. zjazdu poruszała problematykę twórczości kobiet, nazywając to zagadnieniem trudnym i niewdzięcznym, w wyzwoleniu kobiety upatrywała nie tylko szansy na podźwignięcie jej zdolności z zakresu sztuki, ale także korzyści dla sztuki w ogóle. H. Witkowska, Wspomnienia..., s. 7, 8.

26 M. Dulębianka, Zjazd kobiet w Wiedniu, „Głos Kobiet” 1912, nr 148, s. 5, 6. 
a w walce już wyczerpanym. Ale na to musimy mieć pełnię praw obywatelskich i tego żądamy... ${ }^{27}$.

Jej bój, prócz płomiennych przemów, objawiał się także w bardziej praktyczny sposób, mianowicie walczyła o dopuszczenie kobiet do Krakowskiej Akademii Sztuk Pięknych, co wówczas było niemożliwe. Kobiety polskie, by pobierać nauki z zakresu malarstwa, mogły uczęszczać jedynie do szkół prywatnych, które według M. Dulębianki nie mogły zaoferować adeptkom „ani dostatecznych środków, ani dostatecznych ułatwień do pracy"28, gdyż prócz służenia sztuce, musi także uwzględniać korzyści swoich uczniów. Dlatego też tak intensywnie agitowała za dostępem kobiet do akademii państwowych.

Przygotowała $\mathrm{w}$ tym celu płomienny artykuł, zamieszczony w „Sterze"29, który z powodzeniem można nazwać petycją do dyrekcji Szkoły Sztuk Pięknych w Krakowie. Artystka pisała o problemach, jakie wynikały z nauki w zagranicznych szkołach sztuk pięknych, zarówno publicznych jak i prywatnych, a także dysproporcjach, jakie pomimo możliwości uczęszczania do tychże placówek nadal napotykały kobiety ${ }^{30}$. Dosyć istotna z punktu widzenia artystki była także wrażliwość, technika malarska charakterystyczna i unikalna dla każdej szkoły, którą uczniowie w niej nabywali - „Malować cudzą techniką - to grać cudzą ręką"31. Dlatego też jeśli Polki, bądź Polacy decydowali się na edukację w tym kierunku za granicą, winni być już ukształtowani jako artyści, gdyż tylko wtedy „studja u obcych pożytek przynieść mogą" ${ }^{32}$.

M. Dulębianka w omawianym artykule wypowiadała się rozsądnie, zależało jej by możliwość uczęszczania do akademii państwowych była zarezerwowana dla najbardziej zdolnych żeńskich jednostek, nie zaś dla kobiet, które sztukę postrzegały jako szansę wzbogacenia się, bez jakichkolwiek umiejętności i wrażliwości. Prócz walki o dostęp kobiet do państwowych akademii sztuk pięknych, M. Dulębianka starała się także o utworzenie

\footnotetext{
$27 \quad \mathrm{ZNiO}$, rkps 15512/II, k. 32.

28 BNSL, zesp. 9, sygn. 2675, k. 1: „Kołaczcie, a będzie wam otworzono”.

29 Ibidem, k. 3.

30 Dysproporcje te dotyczyły m.in. kwoty uiszczanej przez adeptów i adeptki, koszt półdniowej nauki w szkole Julian’a w przypadku mężczyzn wynosił 25 franków miesięcznie, natomiast kobiety za taką samą ilość czasu, te same warunki płaciły 60 franków: ibidem, k. 3, 5.

31 Ibidem, k. 5.

32 Ibidem, k. 7.
} 
Gimnazjum Żeńskiego we Lwowie, przemawiając w tym celu na zebraniach i uczestnicząc w opracowaniu petycji do Sejmu ${ }^{33}$, czy o dopuszczenie kobiet do sejmu galicyjskiego, o czym będzie mowa poniżej. Prócz powyższych, artystka i aktywistka redagowała także „Głos Kobiet”, będący dodatkiem do „Kuriera Lwowskiego”, czy zamieściła w czasopiśmie „Ster”, napisaną przez siebie nowelę pt. Mańka ${ }^{34}$.

Pierwsze kroki do wprowadzenia kwestii kobiecej wobec planowanych zmian w prawie wyborczym poczyniła już w 1907 r., kiedy to napisała odezwę mającą „ (...) pobudzić kobiety do jakiejś akcji”" ${ }^{35}$, którą następnie rozesłała do stowarzyszeń kobiecych w Krakowie i Lwowie. Spośród tych dwóch ośrodków, jedynie Lwów odpowiedział zorganizowaniem prezydiów stowarzyszeń, po czym przygotowaniem petycji do Sejmu, którą zamieścił na pierwszej stronie „Kurier Lwowski”36. Odezwa Od grona postępowych kobiet... ${ }^{37}$, o umieszczenie czego wnioskowała w liście do redakcji M. Dulębianka, była „żądaniem przyznania przynależnych nam [tj. kobietom - przyp. aut.] obywatelskich praw" ${ }^{\prime 38}$. Postępowe niewiasty trafnie stwierdziły, iż nie tylko wysoce niestosowny, lecz wręcz barbarzyństwem jest fakt, iż prawa wyborcze posiadać może nawet mężczyzna - analfabeta, zaś nawet najbardziej inteligentne spośród przedstawicielek płci pięknej dysponować nim nie mogą. Kobiety pod przewodnictwem M. Dulębianki odwoływały się także do uczuć posłów względem ich matek, sióstr i córek, które pozbawione są praw obywatelskich. Petycja ta była jednak jedynie preludium wydarzeń, które miały nastąpić w przeciągu kilku kolejnych miesięcy.

W 1908 r. ukazała się jedna z bardziej istotnych rozpraw artystki i działaczki, w której poruszała kwestię równouprawnienia kobiet, ujętego w szereg znakomicie ujętych zagadnień politycznych, mianowicie Polityczne stanowisko kobiety:

33 Walka ta została uwieńczona sukcesem w 1918 r.: ibidem, k. 300: Marya Dulębianka. Rzeczniczka etyki i równości obywatelskiej; M. Jaworska, Marja Dulębianka..., s. 13; U. Jakubowska, Lwów na przełomie XIX i XX wieku. Przegląd środowisk prasotwórczych, Instytut Badań Literackich PAN, Warszawa 1991, s. 41.

BNSL, zesp. 9, sygn. 2675, k. 299: Marya Dulębianka. Rzeczniczka etyki i równości obywatelskiej.

ZNiO, rkps 7191/II, k. 171.

„Kurier Lwowski” 1907, nr 476, s. 1.

Ibidem.

Ibidem. 
trzeba było bardzo silnego wstrząśnienia kajdanami wszechniewoli, ażeby i kobietę wyprowadzić z biernego poddaństwa i pchnąć ją do walki. Dziś już pchniętą została. Uczuła nareszcie, że czas i jej stanąć do wspólnej pracy na wielkiej arenie publicznego życia. Że i jej należą się wszystkie obywatelskie prawa, wszystkie bez wyjątku, aby mogła spełniać wszystkie obywatelskie obowiązki39.

Polityczne stanowisko... zostało także zaprezentowane podczas Zjazdu Kobiet Polskich w Warszawie i ogłoszone w dwóch numerach „Steru”" W lutym 1908 r. dokonała także założenia z inspiracji Komitetu Reformy Gospodarki Miejskiej, Związku Równouprawnienia Kobiet ${ }^{41}$, wyłonionego z Komitetu Pracy Oświatowej im. Marii Wysłouchowej ${ }^{42}$. W dość krótkim czasie Komitet z M. Dulębianką jako przewodniczącą rozpoczął gorączkową i pełną zapału pracę. 22 lutego 1908 r. na posiedzeniu w hotelu Victoria z Komitetem Reformy Gospodarki Miejskiej, Komitet Równouprawnienia Kobiet zażądał postawienia kobiecej kandydatury do Sejmu. Podstawą prawną tego kroku była ustawa o ordynacji wyborczej, pozwalająca na interpretację ekstensywną, która nie stwierdzała jednoznacznie, że uprawnionym wyborcą mógł być jedynie mężczyzna. Komitet Reformy Gospodarki Miejskiej wraz z Polskim Stronnictwem Ludowym i Postępowo-Demokratycznym wyrazili zgodę na jedno miejsce dla kobiety na swojej liście. Komitet Równouprawnienia Kobiet wysunął kandydaturę swojej przewodniczącej. Motywy związania się Komitetu z partią polityczną, w tym przypadku PSL, a także działania Komitetu w sprawie

39 M. Dulębianka, Polityczne stanowisko kobiety, Skład Główny w Administracji „Steru”, Warszawa 1908.

„Ster. Organ równouprawnienia Kobiet. Warszawa” 1907, nr 7, z. 8; J. Cabaj, Główne płaszczyzny aktywności kobiet $w$ świetle ich trójzaborowych zjazdów $w$ latach 1905-1918, „Dzieje Najnowsze” 2008, t. 40, nr 4, s. 34.

41 Przekształconego później w Komitet Pracy Obywatelskiej Kobiet: A. Augustynowicz, Marja Dulębianka (w dziesiątą rocznicę zgonu), „Praca Obywatelska” 1929, nr 5(8), s. nlb.

42 Skład wydziału Komitetu: przewodnicząca - M. Dulębianka, posiadająca trzy zastępczynie: A. Augustynowiczową, M. Bersonową i Z. Skrzetelską-Grynberg, tyle samo sekretarek: J. Dobrowolską, J. Rygłównę, M. Zieniewską, skarbniczkę O. Dekańską. Pozostałymi członkiniami wydziału były m.in.: R. Buchbinderowa, A. Lewicka, J. Tomicka S. Wekslerowa: CPHAUL, zesp. 841, inw. 1, sygn. 159, k. 2, 7: Sprawozdanie z czynności „Komitetu Równouprawnienia Kobiet we Lwowie”. 
praw wyborczych, wyjaśniła działaczka i artystka w tekście Stronnictwo jutra ${ }^{43}$.

Maria Dulębianka, choć finalnie jej mandat został unieważniony, ze względu na nieposiadanie przez nią czynnego prawa wyborczego, aktywnie uczestniczyła w wiecach, organizowała je oraz wygłaszała swoje postulaty, jak 28 lutego, czy 1 marca $1908 \mathrm{r}^{44}$ :

Pierwszy postulat t.j. reforma wyborcza do sejmu jest już niemal na porządku dziennym. Ci, co ją przeprowadzać będą, muszą pamiętać, że tylko zupełne równouprawnienie wszystkich obywateli - wszystkich bez wyjątku i bez różnicy płci, może nam dać siłę i potrzebny pęd i potrzebny nastrój do wyzwolenia się spod obcej kurateli ${ }^{45}$.

Zainteresowanie i poparcie jej akcesu doskonale obrazują wyniki wyborów z 2 marca 1908 r., wedle których otrzymała ona 511 głosów, co stanowiło 10\% wszystkich. Gros z nich oddali mężczyźni, bowiem aż 411, co ukazuje nie tylko widoczną potrzebę uregulowania kwestii kobiecej, ale też oddziaływanie i charyzmę M. Dulębianki. Przewodnicząca Komitetu Równouprawnienia Kobiet była świadoma, iż potencjalna wygrana w wyborach zostanie unieważniona, chodziło jednak o coś innego, mianowicie o wykonanie pierwszego kroku, pewnego wyłomu i upublicznienie kwestii równouprawnienia obywatelskiego kobiet ${ }^{46}$. Konkretnym rezultatem akcji kobiecych była m.in. uchwała PSL, która domagała się czteroprzymiotnikowego prawa wyborczego do Sejmu, nie tylko dla mężczyzn, ale także i kobiet ${ }^{47}$, natomiast połączone stronnictwa demokratyczne i osobno

43 M. Dulębianka, Stronnictwo jutra. Odczyt wypowiedziany we Lwowie, dnia 2. października 1909 roku w sali ratuszowej, Nakładem Związku Równouprawnienia Kobiet, Lwów 1909, s. 3, 4.

BNSL, zesp. 9, sygn. 2675, k. 277.

W przemówieniu tym M. Dulębianka poruszyła także kwestię Rusinów, reformę szkolną, czy finansową: ibidem, k. 19: Mowa kandydatki na posła do Sejmu krajowego, p. Marji Dulębianki.

Komitet Równouprawnienia Kobiet postulował równości wobec prawa wszystkich obywateli obu płci, pełnego dostępu do pracy o charakterze społecznym i narodowym, a także wyzwolenia kobiet w sferach polityki, prawa, nauki, a także kwestii finansowych: CPHAUL, zesp. 841, inw. 1, sygn. , sygn. 159, k. 3: Sprawozdanie z czynności „Komitetu Równouprawnienia Kobiet we Lwowie”.

M. Dulębianka, W sprawie równouprawnienia kobiet, „Kurier Lwowski” 1908, nr 464, s. 1, 2; Eadem, Stronnictwo jutra..., s. 5. 
narodowo-demokratyczne domagały się czynnych i biernych praw wyborczych dla kobiet z ograniczającym je cenzusem ${ }^{48}$.

Komitet prócz kwestii typowo politycznych, zajmował się także bardziej przyziemnymi. Mając na uwadze trudną sytuację finansową wielu polskich kobiet, które wymagałyby pomocy prawnej, powołał Biuro bezpłatnej porady prawnej, otwarte w każdą niedzielę od godziny 10 do $11^{49}$. Komitet założony przez M. Dulębiankę żywo interesował się także kwestiami naukowymi, tj. warunkami, w jakich Polki odbywały studia na uniwersytetach i uczelniach zagranicznych. Stworzył nawet specjalną ankietę, w której kobiety miały szansę przybliżyć okoliczności wstąpienia w szeregi studentów, co zwrócić miało uwagę społeczeństwa na konieczność wprowadzenia reform odnośnie ich wychowania i wykształcenia ${ }^{50}$.

W latach 1911-1913 utworzyła we Lwowie „Wyborczy Komitet Kobiet do Rady Miejskiej”, z własną listą kandydatów, założyła także we Lwowie w 1913 r. Ligę Mężczyzn dla Obrony Praw Kobiety ${ }^{51}$, czy Komitet Pracy Obywatelskiej Kobiet z szeroko zakreśloną działalnością polityczną, prawną, etyczną i ekonomiczną ${ }^{52}$.

W programie, przedłożonym podczas pierwszego zgromadzenia 15 stycznia 1912 r. członkinie postanowiły uregulować swoją orientację

$48 \quad$ Podczas kolejnych posiedzeń sejmu projekt ten przepadł, w związku z zarzutem postawionym przez koła ziemiańskie, jakoby liczba mandatów im przypadających uległa zmniejszeniu, wobec czego kwestia przyznania kobietom praw wyborczych zeszła na drugi plan. Wobec tego, a także licznych obietnic ze strony niemal wszystkich stronnictw kobiety na czele z M. Dulębianką przystąpiły do jeszcze aktywniejszego działania, co znalazło odzwierciedlenie m.in. na łamach „Głosu Kobiet”: Eadem, O prawa polityczne kobiet, „Głos Kobiet” 1912, nr 8, s. 5.

49 Biuro to było prowadzone przez M. Bersonową i Z. Litwinowiczową: CPHAUL, zesp. 841, inw. 1, sygn., sygn. 159, k. 3: Sprawozdanie z czynności „Komitetu Równouprawnienia Kobiet we Lwowie".

$50 \quad$ BNSL, zesp. 9, sygn. 2675, k. 253, 255: Ankieta w sprawie studentek Polek zagranicznych uniwersytetów oraz wyższych i specjalnych kursów.

51 W skład Ligi Mężczyzn weszli: prof. Thulie, dr W. Lewicki, Mikołajski i inni: ibidem, k. 299; M. Jaworska, Marja Dulębianka..., s. 14.

52 Nazwa nowo powstałego zrzeszenia była jedynie formą konstrukcyjną, ze względu na $\$ 30$ ust. o stowarzyszeniach, która wzbraniała kobietom przynależeć do stowarzyszeń o charakterze politycznym. Postanowienie to miało wkrótce zostać zniesione stosownym projektem, który oczekiwał na zatwierdzenie: CPHAUL, zesp. 841, inw. 1, sygn. 122, k. 94: Życiorys Marii Dulębianki; Nowa organizacja kobiet, „Głos Kobiet” 1912, nr 32, s. 6. 
polityczną ${ }^{53}$, by móc uzyskać dla swojego ruchu prawne podstawy, określić pragnienia i żądania odnośnie ustroju wewnętrznego, a także stosunków względem mniejszości, jak Rusini w Galicji, czy Litwini w Królestwie Polskim. Ponadto, za najistotniejszy cel, prócz walki o kwestię kobiecą, była praca na rzecz wyrwania kraju spod jarzma niewoli ${ }^{54}$. Członkinie z M. Dulębianką na czele postanowiły działać w myśl zasady „chcę, żeby mi było dobrze, lecz nie może mi być dobrze, gdy źle jest tobie" ${ }^{55}$, nie zaś chrześcijańskiej maksymy „Kochaj bliźniego...”, ze względu na egoizm, którego jednostka ludzka nie jest w stanie się wyzbyć.

Prócz powyższych, nadrzędnym zadaniem Komitetu było przygotowanie kobiet do pracy społecznej i politycznej, „aby rozszerzyć ramy działalności zapoczątkowanej przez grono osób grupujących się około naszej redakcji [tj. „Głosu Kobiet” - przyp. aut.] i zszeregować postępowe żywioły kobiece do pracy obywatelskiej" ${ }^{56}$. Członkinie, prócz kwestii praw wyborczych, zauważały także inne, istotne problemy jak: reforma szkolnictwa, instytucji wychowawczych, a także pozostałych placówek o charakterze społecznym, obyczajowym.

Autorka $^{57}$ artykułu poświęconego założeniu Komitetu Pracy Obywatelskiej Kobiet poczyniła trafną uwagę, iż fakt przyznawania kobietom

53 Członkinie postanowiły założyć w przyszłości własne zrzeszenie polityczne, pod nazwą „Stronnictwo jutra”, które realizowałoby się nie tylko w słowach, lecz przede wszystkich czynach na rzecz „słabych i krzywdzonych”. Jednak głównym powodem tegoż postanowienia było stanowisko ówczesnych partii, które pomimo szumnych deklaracji, stosowały system podwójnej równości, etyki, czy prawa. Natomiast członkinie Komitetu propagowały hasła uczciwości politycznej, a także prawa obywatelskiego, z którego nikt, prócz nieletnich, przestępców, czy umysłowo chorych nie może być wykluczony. Zob. Nowa organizacja kobiet, „Głos Kobiet” 1912, nr 32, s. 6.

54 Pierwsze spotkanie 15.01.1912 r. odbyło się w lokalu Stowarzyszeń kobiecych przy ul. Batorego 36 we Lwowie (ob. ul. Kniazia Romana). Zarząd Komitetu z M. Dulębianką na czele wstąpił do oddziału żeńskiego „Związku Strzeleckiego”, zorganizowanego we Lwowie: A. Augustynowicz, Marja Dulębianka..., s. 8; Komitet pracy obywatelskiej kobiet, „Głos Kobiet” 1912, nr 8, s. 6; Nowa organizacja kobiet, „Głos Kobiet” 1912, nr 32, s. 5, 6; dodatek do: M. Orłowicz, Ilustrowany przewodnik po Lwowie. Plan stołecznego królewskiego miasta Lwowa z 1894 r., Wydawnictwo „Ruthenus”, Krosno 2004, s. 1.

55 Nowa organizacja kobiet, „Głos Kobiet” 1912, nr 32, s. 6.

56 Ibidem, s. 5.

57 Autorka artykułu Nowa organizacja kobiet zamieszczonego w „Głosie Kobiet” nie jest znana z imienia i nazwiska w związku z brakiem jakichkolwiek inicjałów pod tekstem. 
z innych krajów praw wyborczych nie był efektem ich bardziej aktywnej pracy na tym polu, lecz lepszej organizacji i współpracy, dlatego też powstanie Komitetu Pracy Obywatelskiej Kobiet było tak istotne.

Teoretycznie wszyscy uznajemy potrzebę organizacji, wszyscy oceniamy korzyści i moc, jaką ona daje każdej pracy i każdemu przedsięwzięciu, a przecież przyznać trzeba, że naszą właściwością, właściwością naszej narodowej indywidualności jest nieumiejętność współpracy, wytrwałego współdziałania, co też było niewątpliwie przyczyną niejednej z naszych klęsk. I my kobiety, cierpimy na to niedomaganie ${ }^{58}$.

Dulębianka jako przewodnicząca tegoż Komitetu zainicjowała w 1912 r. zjazd delegatek stowarzyszeń kobiecych krajów i narodów, które wchodziły w skład Imperium Habsburgów, by wspólnie stawić czoła parlamentowi ${ }^{59}$. Komitet zorganizował szereg stowarzyszeń mających pieczę nad dziećmi, czy angażował się w kwestię kobiecą odnośnie praw wyborczych, a także pierwszą kobiecą kooperatywę „Spółkę budowlaną” w związku z utworzeniem „Domu kobiet im. Marji Konopnickiej”, który służyć miał różnym stowarzyszeniom kobiecym i zebrać je wszystkie pod wspólnym dachem ${ }^{60}$. Przedsięwzięcia tego, tj. zbudowania jednego, dużego gmachu nie udało się zrealizować ze względu na zapis prawny, zgodnie z którym właścicielem owego budynku mogłoby być tylko jedno stowarzyszenie, reszta zaś musiałaby unormować swój stan posiadania za pomocą wewnętrznego regulaminu. Dlatego też postawiono na budowę kilku domów kobiecych na zasadzie kooperatywy. „Dom im. Marji Konopnickiej” miałby dostarczać tanich mieszkań, a także ułatwiać warunki kobietom samodzielnie pracującym, „(...) iżby stał się miłem ogniskiem dla pozbawionych rodziny i terenem, na którym mogłyby się zapoznawać i zbliżać ze sobą kobiety wszelkich warstw, w różnych zawodach pracujące" ${ }^{61}$. Wspomniana wcześniej spółka 24 czerwca 1912 r. ukonstytuowała się na walnym zgromadzeniu, a w szeregach dyrekcji, prócz Bolesława Lewickiego, znalazła się także Dulębianka $^{62}$.

$58 \quad$ Nowa organizacja kobiet, „Głos Kobiet” 1912, nr 32, s. 6.

59 M. Jaworska, Marja Dulębianka..., s. 15.

60 BNSL, zesp. 9, sygn. 2675, k. 301: Marya Dulębianka. Rzeczniczka etyki i równości obywatelskiej.

61 Dom kobiet im. Marji Konopnickiej, „Głos Kobiet” 1912, nr 306, s. 5.

62 Dyrekcja: Maria Dulębianka, Bolesław Lewicki, Zdzisława Kowarzowa, Pelagia hr. Skarbek, Helena Feldsteinowa, Józefa Szczepańska. W radzie nadzorczej znaleźli 
M. Dulębianka objęła ponadto redakcję dodatku do „Kuriera Lwowskiego", mianowicie "Głosu Kobiet”, gdzie poruszała rozmaite kwestie kobiece i narodowe ${ }^{64}$, jak np. sprzeciw wobec projektu oderwania Chełmszczyzny ${ }^{65}$ - zawiązała „Komitet Chełmski”, na czele którego stanęła, całkowicie angażując się w osiągnięcie założonego przez siebie celu. Zbierała podpisy, rozsyłała odezwy do posłów, memoriały do przedstawicieli innych nacji, w których nawoływała, by nie pozostawali obojętni wobec działań Imperium Rosyjskiego. Swoje działania i żądania umotywowała powołaniem się na paragraf zawarty $\mathrm{w}$ aktach kongresu wiedeńskiego, który mówił, iż „prawa Polaków są odtąd pod opieką Europy”66.

Jej zaangażowanie i poświęcenie rozmaitej liczbie organizacji i potrzeb nie tylko kobiet doskonale obrazują słowa zawarte w wydaniu tygodnika „Na Posterunku”, w w całości poświęconego osobie M. Dulębianki:

Któż nie pamięta tej drogiej, tak znanej we Lwowie postaci, w nasuniętym małym kapeluszu na głowie, $\mathrm{z}$ teczką pod pachą, $\mathrm{z}$ parasolem na ręce, zawsze spieszącej bez wytchnienia z Poradni do Magistratu, z Magistratu do Komitetu, $\mathrm{z}$ posiedzenia na posiedzenie, $\mathrm{z}$ narady jednej na drugą - dla dobra

się: Anna Lewicka, prof. B. Pawlewski, dr St. Feuerstein, Sabina Jaworska, dr T. Rutowski, wiceprezydent m. Lwowa, Józefa Czarnowska, Jan Paszkudzki, H. Maurizio, dr Jan Hozer, Tadeusz Moszyński. Zastępcami byli: Wł. Jankowska, Maria Gostyńska, dr J. Pannenko, St. Bieńkowska, H. Pawlewska, J. Próchnicka. Komisja rewizyjna: A. Aleksandrowiczówna, Eugenia Bartoniówna, dr Aleksander Lisiewicz. Ibidem, s. 5 .

J. Myśliński, Studia nad polska prasa społeczno-polityczna w zachodniej Galicji 1905-1914, [w:] T. Cieślak, T. Jabłoński (red.), Materiały i studia do historii prasy i czasopiśmiennictwa polskiego, z. 16, Państwowe Wydawnictwo Naukowe, Warszawa 1970, s. 204; J. Jarowiecki, Prasa lwowska w latach 1864-1918, Wydawnictwo Naukowe Akademii Pedagogicznej, Kraków 2000, s. 208.

$\mathrm{Na}$ przykład kwestie związane z wyborami do parlamentu austriackiego, Rady Miejskiej, jubileuszu P. Kuczalskiej-Reinschmit, równouprawnienia kobiet, nowych miejsc pracy dla kobiet itp. zob.: dodatek do „Kuriera Lwowskiego”, „Głos Kobiet”, 1911, nr 150, s. 5; 1911, nr 174, s. 5, 6; 1911, nr 196, s. 5, 6; 1911, nr 220, s. 5; 1911, nr 264, s. 5; 1911, nr 286, s. 5; 1911, nr 308, s. 5, 6; 1911, nr 332, s. 5, 6; 1911, nr 424, s. 5,$6 ; 1911$, nr 446, s. 5,6 . 
instytucyi, rozwiązania jakichś trudności, wyszukania sposobów i ludzi dla zaradzenia jakiejś biedzie czy potrzebie ${ }^{68}$.

W 1912 r. brała czynny udział w organizacjach strzeleckich. Przed wybuchem wojny Komitet Pracy Obywatelskiej Kobiet rozpoczął pracę nad tematami: Zadania kobiet podczas wojny, czy Stanowisko kobiety - Polki $w$ obecnej sytuacji politycznej ${ }^{69}$. M. Dulębianka podczas spotkań, na których rozprawiano na tematy powyższe, zachęcała kobiety do czynienia przygotowań do udziału w możliwych bojach, które mogą przynieść upragnioną wolność ojczyźnie. Wskazywała i wytyczała nowe kierunki i formy pracy, jakich wymagały od kobiet ówczesne warunki i nowoczesny sposób prowadzenia walki.

Konieczność otrzymywania stałego zarobku zmusiła ją do objęcia funkcji kustosza Miejskiego Muzeum Przemysłowego we Lwowie ${ }^{70}$. W czasie okupacji miasta przez wojska rosyjskie piastowała godność inspektora Miejskiego Urzędu Opieki Generalnej nad Matką i Dzieckiem przez dwa lata, co było sukcesem, gdyż przyznanie kierownictwa nad tą placówką kobiecie było efektem usilnej walki M. Dulębianki ${ }^{71}$. Kierowała także organizacjami charytatywnymi, czy interweniowała u najwyższych władz austriackich w sprawie uwięzionych na Węgrzech ${ }^{72}$.

Blisko współpracowała z prezydentem Tadeuszem Rutowskim, odbyła niebezpieczną podróż do Szwajcarii w celu uzyskania pomocy tamtejszego

A. Augustynowicz, Z codziennych dni, „Na Posterunku” 1919, nr 4, s. 7.

„Stanowisko kobiety - Polki w obecnej sytuacji politycznej” podjęła m.in. na wiecu kobiet w Tarnopolu z 19.12.1912 r. Maria Dulębianka nakreśliła rozwój odradzającej się idei niepodległości Polski, ponadto zaakcentowała rolę kobiety. Po wystąpieniu Dulębianki postanowiono zawiązać organizację kobiet opartą o szeregi Sokoła: BNSL, zesp. 9, sygn. 2675, k. 301: Marya Dulębianka. Rzeczniczka etyki i równości obywatelskiej; Wiec kobiet, „Głos Kobiet” 1911, nr 590, s. 6.

M. Jaworska, Marja Dulębianka..., s. 5.

71 „Nie poprzestawała na «urzędowaniu» i sprawiedliwem rozdawnictwie świadczeń, ale schodziła często do bezsłonecznych suteryn i odwiedzała więdnące tam «blade kwiaty ludzkie»”. H. Witkowska, Opieka społeczna, „Na Posterunku” 1919, nr 4, s. 10; M. Jaworska, Marja Dulębianka..., s. 5.

72 Jako przewodnicząca Komitetu Obywatelskiego Polek, powstałego po rozwiązaniu przez władze austriackie Ligi Kobiet z połączenia byłej Ligi z Komitetem Pracy Kobiet: BNSL, zesp. 9, sygn. 2675, k. 249: Petycja do Naczelnych Władz Wojskowych w sprawie uwięzionych Legionistów; M. Micińska, Inteligencja na rozdrożach 1864-1918, [w:] J. Jedlicki (red.), Dzieje inteligencji polskiej do roku 1918, Wydawnictwo Neriton, Warszawa 2008, s. 125, 126. 
Komitetu dla Lwowa, a także znajomością przepisów i dyplomacją chroniła powierzone jej instytucje przed rekwizycją. W ramach swej działalności zorganizowała kilka sklepów, z których spożywczy zaopatrywała przy pomocy Komitetu Książęco Biskupiego ${ }^{73}$. Zajmowała się także wyrobem torebek papierowych dla Aprowizacji Miejskiej, która sowicie wynagradzała swoje pracownice, oferując przy tym najniższą cenę za sprowadzane wyroby. Z dochodów tych utrzymywano także kuchnię przeznaczoną dla rodzin legionistów oraz rozdawano stypendia czy udzielano małych zapomóg dla byłych żołnierzy legionowych, rozlokowanych w więzieniach w Huszt, czy Szczypiornie ${ }^{74}$.

Doskonałym przykładem obrazującym odwagę i niezłomność, a także niebywałą aktywność M. Dulębianki jest jej wyprawa do Warszawy, w celu dotarcia do Rady Regencyjnej w związku z nieprzychylną polityką względem spraw polskich w czasie działań wojennych. Nie zważała na niebezpieczeństwo wynikające nie tylko z podróży w czasie walk, ale także podróży jako kobieta, zdołała uzyskać w tym celu paszport na zjazd kobiet do Radomia. Dalsza podróż wydawała się niewykonalna, ponieważ otrzymała zakaz przyjazdu do Warszawy, jednak to nie przeszkodziło jej odbyć tej części drogi, trwającej blisko półtorej doby, na furze przemytników, dzieląc niewygodne siedziska wykonane z okrąglaków z Marią Bruchnalską oraz dwudziestoma trzema Żydami. W czasie podróży bagaże M. Dulębianki poddano rewizji i niemal odkryto papiery przeznaczone dla Rady Regencyjnej, udało jej się jednak dotrzeć do Warszawy i uzyskać audiencję u księcia Zdzisława Lubomirskiego, jednego z regentów ${ }^{75}$.

W 1918 r., w czasie walk polsko-ukraińskich, pomimo całej sympatii do tego narodu, wyrażanej m.in. w przemówieniu z 28 lutego $1908 \mathrm{r}^{76}$, organizowała wszelkiego rodzaju pomoc dla walczących na wysuniętych pozycjach bojowych. Działała także aktywnie w Komitecie Obywatelskim Kobiet ${ }^{77}$,

73 CPHAUL, zesp. 841, inw. 1, sygn. 122, k. 94: Życiorys Marii Dulębianki.

74 Ibidem.

75 Ibidem, k. 95.

76 BNSL, zesp. 9, sygn. 2675, k. 19: Mowa kandydatki na posła do Sejmu krajowego, p. Marji Dulębianki.

77 Był on połączeniem Komitetu Pracy Obywatelskiej Kobiet z Ligą Kobiet, prześladowaną przez policję. M. Dulębianka postanowiła połączyć Ligę z istniejącym przed wojną Komitetem Obywatelskim Polek: CPHAUL, zesp. 841, inw. 1, sygn. 122, k. 95: Życiorys Marii Dulębianki; BNSL, zesp. 9, sygn. 2675, k. 304: O Maryi Dulębiance w czasie wojny; H. Waniczkówna, Lwowskie Koło Ligi Kobiet, [w:] M. Rychterówna (red.), Służba ojczyźnie. Wspomnienia uczestniczek walk o niepodległość 1915-1918, Główna Księgarnia Wojskowa, Warszawa 1929, s. 156. 
bądź Komitecie Obywatelskim Polek ${ }^{78}$, wspierała formującą się służbę kurierską w ramach Komitetu. Pracowała także w Naczelnym Tymczasowym Komitecie Rządzącym, w Izbie Handlowej, prowadziła rozmowy ze stroną francuską, m.in. ze względu na doskonałą znajomość tego języka „(...) z łatwością wypowiada przed dostojnikami Francji swoje i społeczeństwa polskiego poglądy" ${ }^{\prime \prime}$.

W grudniu $1918 \mathrm{r}^{80}$. na zjeździe Ligi Kobiet w Warszawie została wybrana na przewodniczącą, jednakże zrezygnowała z pełnienia tej godności, usprawiedliwiając się pracą zawodową we Lwowie i warunkami życia, które uniemożliwiały jej przeprowadzkę do stolicy i pełnienie funkcji przewodniczącej:

„Nie nalegajcie - mówiła - ja przecież sama najgoręcej pragnęłabym stanąć na czele Ligi, nadać jej kierunek odpowiadający moim poglądom i przekonaniom. Uczyniłabym zeń wielką kobiecą organizacyę do pracy nad moralnem odrodzeniem narodu, do walki ze złem, krzewiącem się na naszej wyzwolonej ziemi... Otwiera się tu przed nami szerokie pole działalności, które bezzwłocznie przeorać by należało... Ale ja się już tego podjąć nie mogę... nie mogę..." powtarzała jakoby zmagając się ze sobą wewnętrznie ${ }^{81}$.

W tym czasie, w uznaniu zasług jej pracy na polu społecznym przed I wojną światową, postanowiono wysunąć ją na stanowisko ministra opieki społecznej w pierwszym sejmie wolnej Polski, jednak zamysłu tego nie zrealizowano ze względu na śmierć $M$. Dulębianki ${ }^{22}$.

Przedwczesne odejście wynikało z jej zaangażowania i całkowitego poświęcenia, bowiem w czasie kontroli warunków życia jeńców polskich w obozach ukraińskich, jako delegatka Czerwonego Krzyża, a także człon-

78 Wedle A. Augustynowiczowej, „Praca Obywatelska” 1929, nr 5, s. 9.

79 CPHAUL, zesp. 841, inw. 1, sygn. 122, k. 95: Życiorys Marii Dulębianki.

80 Dokładniej między 29 a 31.12.1918 r. Zob.: K. Cybulska, Działalność Ligi Kobiet Polskich we Lwowie w latach dwudziestych XX wieku, [w:] M. Przeniosło, L. Michalska-Bracha (red.), Znani i nieznani międzywojennego Lwowa. Studia i materiały, t. 4, Wydawnictwo Uniwersytetu Jana Kochanowskiego, Kielce 2015, s. 93, 94, 95.

81 H. Witkowska, Wspomnienia, „Na Posterunku”, s. 8.

82 Na zjeździe Ligi Kobiet w Krakowie w listopadzie 1918 r., gdy omawiano po raz pierwszy kwestię kandydatur kobiecych do tek ministerialnych, postanowiono, iż kobiety powinny przede wszystkim ubiegać się o ministerstwo opieki społecznej, a za najwłaściwszą kandydatkę uznano właśnie M. Dulębiankę: H. Witkowska, Opieka społeczna, „Na Posterunku”, s. 10. 
kini lwowskiej Rady miejskiej ${ }^{83}$ zaraziła się tyfusem, po czym zmarła we Lwowie 7 marca $1919 \mathrm{r}^{84}$. Pogrzeb ${ }^{85}$ był prawdziwym hołdem złożonym wielkiej i zasłużonej Polce, zgromadziły się na nim tłumy, począwszy od prostych robotników, przez inteligencję, młodzież i najwyższych przedstawicieli władz miasta Lwowa ${ }^{86}$. Dekretem prezydenta RP, Ignacego Mościckiego została odznaczona Krzyżem Niepodległości ${ }^{87}$, a także odznaką honorową Polskiego Czerwonego Krzyża ${ }^{88}$.

Niestrudzona działaczka społeczno polityczna, znana we Lwowie przez tysiące osób, zwłaszcza podczas inwazji rosyjskiej i okupacji ukraińskiej, niosła słowa pociechy, otuchy, wytrwania. Spełniając misję Czerwonego Krzyża (...) zaraziła się tyfusem (...) i przypłaciła życiem swe poświęcenie. Czcząc jej zasługi Rada m. Lwowa nazwała jej imieniem jedną z ulic Lwowa ${ }^{89}$.

\section{Podsumowanie}

M. Dulębianka w czasie swego aktywnego życia domagała się nie tylko przyznania jak najszerszych praw kobietom, pragnęła także dla nich większego zaangażowania w pracę społeczną i polityczną oraz utworzenia silnej organizacji kobiecej. $Z$ biegiem lat jej pogląd na wyżej wymienione kwestie, na przyszłą rolę kobiety zarówno w życiu społecznym, jak i politycznym konkretyzował się. M. Dulębianki nie zadawalało już zrównanie pozycji kobiety z mężczyzną, pragnęła, by płeć piękna ożywiła zatęchłą atmosferę, jaka panowała w zdominowanym przez mężczyzn świecie polityki, by kobiety były prawdziwymi realizatorkami haseł zawartych zarówno w Poli-

83 Semper Fidelis. Obrona Lwowa w obrazach współczesnych, Wydawnictwo Towarzystwa Straż Mogił Polskich Bohaterów, Lwów 1930, s. 167.

ZNiO, rkps 15512/II, k. 33.

Odbył się 10 marca 1919 r. o godzinie 14 w kaplicy przy ul. Piekarskiej 52: BNSL, zesp. 9, sygn. 2675, k. 295: Klepsydra M. Dulębianki.

O śmierci M. Dulębianki wspomina także Z. Romanowiczówna w swym dzienniku: „Wczoraj umarła Maria Dulębianka, kobieta tak wielkiej miary, że Jej dwadzieścia innych zastąpić nie zdoła”. Z. Romanowiczówna, Dziennik lwowski 1842-1930, t. 2, Anchor Books, Warszawa 2005, s. 313.

„Monitor Polski”, 31.12.1930, s. 1.

Polski Czerwony Krzyż. Sprawozdanie za 1935 rok, Drukarnia Piotr Pyz i S-ska, Warszawa 1936, s. 11.

Orlętom. Straż mogił polskich bohaterów..., s. 28. 
tycznym stanowisku kobiety, jak i Stronnictwie jutra, by obrały własny kierunek, własną drogę, po której będą podążać, gdyż żadne $\mathrm{z}$ istniejących wówczas stronnictw nie realizowało i nie mogło urzeczywistnić pojęć bliskich kobietom.

\section{Bibliografia}

\section{Źródła archiwalne i biblioteczne}

Centralne Państwowe Historyczne Archiwum Ukrainy we Lwowie, Zesp. 841, inw. 1, sygn. 122, 159.

Lwowska Naukowa Biblioteka im. Wasyla Stefanyka we Lwowie, Zesp. 9, sygn. 2675.

Zakład Narodowy im. Ossolińskich we Wrocławiu:

- rkps. 7191/II, k. 171;

- rkps. 15512/II, k. 31, 32, 33.

\section{Źródła publikowane}

Byk E., Marya Dulębianka jako malarka. Z powodu pośmiertnej wystawy Jej utworów, „Wiek Nowy” 1919, nr 5405, s. nlb.

Dulębianka M., Polityczne stanowisko kobiety, Skład Główny w Administracji Steru, Warszawa 1908.

Dulębianka M., Stronnictwo jutra. Odczyt wypowiedziany we Lwowie, dnia 2. października 1909 roku w Sali ratuszowej, Nakładem Związku Równouprawnienia Kobiet, Lwów 1909.

„Głos kobiet” - numery z roku 1911, 1912.

Jaworska M., Marja Dulębianka, Lwowska Liga Kobiet, Lwów 1929.

„Kurier Lwowski” - numery z roku 1884, 1907, 1908.

„Monitor Polski”, 31.12.1930.

„Na Posterunku” - numery z roku $1919 \mathrm{r}$.

Orlętom: straż mogił polskich bohaterów: przewodnik po cmentarzu obrońców Lwowa, Wydawnictwo: Towarzystwo Straży Mogił Polskich Bohaterów, Lwów 1934.

Polski Czerwony Krzyż. Sprawozdanie za 1935 rok, Drukarnia Piotr Pyz i S-ska, Warszawa 1936.

„Praca Obywatelska” - numer z roku 1929.

Semper Fidelis. Obrona Lwowa w obrazach wspótczesnych, Wydawnictwo Towarzystwa Straż Mogił Polskich Bohaterów, Lwów 1930.

„Ster. Organ równouprawnienia Kobiet. Warszawa” - numery z roku 1907. 
Strug A., Z powrotem, Wydawnictwo Księgarnia Bibljoteki Dzieł Wyborowych, Warszawa 1925.

Waniczkówna H., Lwowskie Koło Ligi Kobiet, [w:] M. Rychterówna (red.), Służba ojczyźnie. Wspomnienia uczestniczek walk o niepodległość 1915-1918, Główna Księgarnia Wojskowa, Warszawa 1929.

\section{Opracowania}

Cabaj J., Główne płaszczyzny aktywności kobiet w świetle ich trójzaborowych zjazdów w latach 1905-1918, „Dzieje Najnowsze. Kwartalnik poświęcony historii XX wieku" 2008, t. 40, nr 4.

Cybulska K., Działalność Ligi Kobiet Polskich we Lwowie w latach dwudziestych XX wieku, [w:] M. Przeniosło, L. Michalska-Bracha (red.), Znani i nieznani międzywojennego Lwowa. Studia i materiały, t. 4, Wydawnictwo Uniwersytetu Jana Kochanowskiego, Kielce 2015.

Fita S., Nieznane listy Marii Konopnickiej i Marii Dulębianki do Stefanii Wekslerowej: 1908-1910, „Pamiętnik Literacki” 2000, t. 91, z. 2.

Jakubowska U., Lwów na przełomie XIX i XX wieku. Przeglad środowisk prasotwórczych, Instytut Badań Literackich PAN, Warszawa 1991.

Jankowski E. (red.), Słownik pseudonimów pisarzy polskich XV w.-1970 r., Wydawnictwo Zakładu Narodowego im. Ossolińskich, Wrocław 1994.

Jarowiecki J., Prasa lwowska w latach 1864-1918, Wydawnictwo Naukowe Akademii Pedagogicznej, Kraków 2000.

Kizwalter T., Procesy modernizacji a emancypacja kobiet na ziemiach polskich w XIX wieku, [w:] A. Żarnowska, A. Szwarc (red.), Kobieta i społeczeństwo na ziemiach polskich w XIX w., Wydawnictwo DiG, Warszawa 1990.

Maj E., Wzorce aktywności kobiet w Narodowej Demokracji (1893-1939), [w:] T. Kulak, M. Dajnowicz (red.), Drogi kobiet do polityki (na przestrzeni XVIII-XXI wieku), Wydawnictwo Chronicon, Wrocław 2016.

Michalska-Bracha L., Marczewska M., Lwowianki wobec równouprawnienia kobiet - trzy historie. Studium historyczno-językoznawcze, „Czasopismo Naukowe Instytutu Studiów Kobiecych" 2019, nr 1(6).

Micińska M., Inteligencja na rozdrożach 1864-1918, [w:] J. Jedlicki (red.), Dzieje inteligencji polskiej do roku 1918, Wydawnictwo Neriton, Warszawa 2008.

Myśliński J., Studia nad polska prasa społeczno-polityczna w zachodniej Galicji 1905-1914, [w:] T. Cieślak, T. Jabłoński (red.), Materiały i studia do historii prasy i czasopiśmiennictwa polskiego, z. 16, Państwowe Wydawnictwo Naukowe, Warszawa 1970.

Orłowicz M., Ilustrowany przewodnik po Lwowie. Plan stołecznego królewskiego miasta Lwowa z 1894 r., Wydawnictwo „Ruthenus”, Krosno 2004.

Romanowiczówna Z., Dziennik lwowski 1842-1930, t. 2, Warszawa 2005. 
Sosnowska J., Maria Dulębianka przeciw samotności, [w:] A. Żarnowska, A. Szwarc (red.), Kobieta i rewolucja obyczajowa. Społeczno-kulturowe aspekty seksualności. Wiek XIX i XX, t. 9, Wydawnictwo DiG, Warszawa 2009.

Szypowska M., Konopnicka jakiej nie znamy, Państwowy Instytut Wydawniczy, Warszawa 1969.

Tomasik K., Homobiografie. Pisarki i pisarze polscy XIX i XX wieku, Wydawnictwo Krytyki Politycznej, Warszawa 2008.

Walęciuk-Dejneka B., Galicyjskie portrety kobiet - Maria Dulębianka, [w:] J. Kamińska-Kwak, D. Opaliński (red.), Kobieta w Galicji. Nowoczesność i tradycja, Rzeszów 2016.

Żarnowska A., Prywatna sfera życia rodzinnego i zewnętrzny świat życia publicznego - bariery i przenikanie (przełom XIX i XX wieku), [w:] A. Żarnowska, A. Szwarc (red.), Kobieta i świat polityki. Polska na tle porównawczym w XIX i w poczatkach XX wieku, Wydawnictwo DiG, Warszawa 1994. 